\title{
MODEL PENGAWASAN PEMBELAJARAN PENDIDIKAN JASMANI DI SD
}

\author{
Yudha M. Saputra \\ Universitas Pendidikan Indonesia (e-mail: m_saputra@yahoo.co.id;
}

HP: 08121492782)

\begin{abstract}
A Model for the Supervision in the Learning of Physical Education in Elementary School. This study aimed to optimize the functions of principals and supervisors in the improvement of physical education teachers' performance. It was a research and development study in which the preliminary steps employed the qualitative approach to obtain information on the existing models at present and attempts to develop one. The result of this study showed that the model for the supervision in the learning of physical education significantly affected the performance of physical education teachers in elementary schools. In other words, the model was effective to improve the quality of teachers' performance and students' achievement.
\end{abstract}

Keywords: supervision model, performance, physical education

\section{PENDAHULUAN}

Pendidikan jasmani menjadi bagian yang tidak terpisahkan dari pendidikan secara keseluruhan. Dalam hal ini, Corbin, et al. (1979:1) menjelaskan bahwa physical education is important of one's total education. Sebagai bagian penting dari pendidikan, pembelajaran pendidikan jasmani secara utuh berperan dalam meningkatkan kualitas peserta didiknya. Terjadinya perubahan perilaku siswa secara positif seperti kebiasaan bergerak, menjaga kebugaran, disiplin, menghargai teman menjadi salah satu indikator pencapaian hasil belajar melalui pendidikan jasmani. Salah satu tantangan terbesar yang harus dihadapi guru pendidikan jasmani saat ini adalah kemampuannya untukmemelihara perilaku siswa untuk dapat belajar dengan sungguh-sungguh dan meraih tujuan pendidikan secara komprehensif. Kondisi faktual menunjukkan bahwa guru pendidikan jasmani dihadapkan pada berbagai persoalan yang sering terjadi terutama perilaku menyimpang yang dilakukan oleh para siswa. Hasil penelitian dari Lavay, et al. (1997:6) telah membuktikan bahwa, "Teachers and parents have cited a lack of discipline and control as one of the major obstacles educators face in teaching students effectively". Kurangnya disiplin dan rendahnya moral para siswa saat ini telah menjadi fokus isu yang perlu ditanggulangi secara cepat dan tepat.

Guru sebagai sumber utama dalam proses pembelajaran di SD, tentunya memiliki tanggung jawab paling besar dalam upaya mengefektifkan pembelajaran. Efektivitas pembelajaran pendidikan jasmani tercermin dalam keterli- 
batan siswa selama dan setelah pembelajaran itu berakhir. Hyland (1990:51) memaparkan, "The essence of good teaching in physical education is that the kids should enjoy the experience and choose to continue to participate in activity when school is over." Hakikat pembelajaran pendidikan jasmani yang baik adalah siswa harus dapat menikmati pengalaman dan memilih untuk melanjutkan keterlibatannya dalam aktivitas tersebut di luar jam pelajaran. Oleh karena itu, pelaksanaan pengawasan perlu dilakukan secara periodik agar kinerja guru pendidikan jasmani dan hasil belajar siswa dapat terpantau secara cermat.

Dalam pelaksanaan pengawasan yang efektif sangat diperlukan berbagai faktor pendukung. Dharma (2001:13) menetapkan bahwa faktor pendukung yang diperlukan dalam pengawasan adalah manusia. Faktor manusia menunjukkan adanya keterlibatan kedua belah pihak, yakni pengawas dan guru. Apabila keduanya saling bersinergi dalam menjalankan tugasnya masingmasing, pelaksanaan pengawasan akan dapat berjalan efektif. Apalagi dengan dukungan supra sarana seperti kebijakan dinas pendidikan dan sarana penunjang seperti sarana pembelajaran, dukungan teknologi, iklim kerja, dan kesejahteraan guru akan lebih menopang terlaksananya proses pengawasan yang efektif.

Penggunaan model pengawasan selama ini belum menjadi tuntutan sehingga pelaksanaan pengawasan belum berjalan secara tepat. Bahkan, pengawas cenderung hanya mengawasi yang berhubungan dengan urusan administratif dan tidak menyentuh hal-hal yang ber- sifat subtantif. Kenyataan itu sering membuat guru pendidikan jasmani kurang diperhatikan. Implikasinya guru menjadi frustasi dan malas dalam mengajar karena suasana kerja menjadi tidak kondusif. Oleh karena itu, pengawas harus memberikan perlakuan yang sama dalam proses pengawasan kepada guru pendidikan jasmani maupun guru kelas. Untuk menanggulanginya, guru sangat memerlukan proses pembinaan dalam berbagai hal agar mampu menciptakan suasana kerja yang lebih kondusif dan positif.

Faktor penghambat dalam efektivitas pembinaan guru lebih pada faktor pribadi; yakni ketidakmampuan para pengawas untuk melaksanakan pembinaan terhadap guru pendidikan jasmani secara efektif karena keterbatasan pengetahuan (knowledge), keterampilan (skills), dan bahkan kepribadiannya (personality). Menurut pernyataan Ketua KKPS (Kelompok Kerja Pengawas Sekolah) se-Kota Bandung tahun 2005 bahwa yang memperburuk citra dan kinerja pengawas sekolah adalah latar belakang pengawas yang tidak menguasai bidangnya serta tidak cukup memiliki motivasi dan peluang yang tinggi dalam menjalankan tugasnya. Dalam Harian Umum "PR" 9 Oktober 2006 hal 17, Furqon menjelaskan bahwa masih ditemukan tenaga pengawas yang tidak menguasai substansi. Oleh karena itu, upaya untuk meningkatkan kemampuan profesional para pengawas harus merupakan suatu keniscayaan.

Penggunaan model pengawasan selama ini belum mendukung terhadap tugas pengawas. Tugas pengawas sebagai pembina profesional yang diberi 
wewenang penuh oleh kepala dinas pendidikan dalam mengontrol kualitas pembelajaran belum berjalan optimal. Data menunjukkan bahwa $80 \%$ guru pendidikan jasmani di Kota Bandung masih belum merasakan secara langsung pembinaan yang diberikan oleh pengawas.

Secara spesifik rumusan masalah ini ditetapkan dalam bentuk pertanyaan penelitian sebagai berikut. (1) Bagaimana model pengawasan pembelajaran pendidikan jasmani saat ini yang dilaksanakan oleh pengawas dikaitkan dengan tugas pokok pengawas sekolah? (2) Seberapa besar efektivitas model pengawasan pembelajaran pendidikan jasmani di SD yang seharusnya dikembangkan?

Melalui pengawasan pembelajaran, pengawas akan mampu mempengaruhi perilaku guru dalam melaksanakan tugasnya sebagai pelaksana proses pembelajaran. Dalam hal ini, Alfonso, et al. (1981:43) menjelaskan bahwa instructional supervision is herein defined as behavior officially designated by the organization that directly affects teacher behavior in such a way as to facilitate pupil learning and achieve the goals of the organization. Pengawasan pembelajaran sebagai upaya yang dilakukan lembaga yang secara langsung memberi pengaruh terhadap perilaku para guru untuk memfasilitasi belajar siswa dan meraih tujuan pendidikan. Demikian pula halnya dengan guru pendidikan jasmani, kinerjanya akan meningkat manakala pelaksanaan supervisi pembelajaran berjalan secara efektif dan efisien.

Pengawasan ini dirancang untuk membantu para guru dalam menjalan- kan tugasnya sebagai pendidik dan pengajar di sekolah. Menurut Sergiovanni dan Starratt (1993:37), secara umum merumuskan bahwa supervision is a process designed to help teachers and supervisors learn more about their practice; to be better able to use their knowledge and skills to better serve parents and schools; and to make the school a more effective learning community.

Dalam melaksanakan pengawasan pembelajaran di sekolah, pemahaman tentang landasan dan siapa yang melaksanakan pengawasan sangatlah diperlukan. Terutama untuk meningkatkan efektivitas dan efisiensi proses pelaksanaan pengawasan pembelajaran pendidikan, menurut Soetjipto dan Kosasi (1999:239), kegiatan supervisi perlu dilandasi oleh beberapa hal, yaitu: (1) falsafah dasar; (2) pendekatan ilmiah; (3) keberhasilan belajar siswa; (4) kontinuitas perbaikan; dan (5) mengembangkan keadaan. Jadi, pengawasan merupakan bantuan kepada guru dalam perbaikan situasi pembelajaran.

Pengawasan dalam model Metzler's memfokuskan pada upaya pembinaan dari pengawas kepada guru sehingga terjalin komunikasi harmonis dari keduanya. Komunikasi akan diawali sebelum pembelajaran itu dimulai dan sifat pengawasannya adalah dilakukan secara langsung oleh pengawas terhadap guru pendidikan jasmani di lapangan untuk membantunya meningkatkan kinerjanya. Pengawas yang menggunakan model ini dalam melakukan pengawasan pembelajaran dapat membantu para guru pendidikan jasmani saat ini dan yang akan datang, dan juga membantu para siswa untuk 
lebih merasakan manfaat pembelajaran pendidikan jasmani di sekolahnya.

Terkait dengan penggunaan model dalam pelaksanaan pengawasan, sekarang ini sudah menjadi bagian yang tidak terpisahkan dalam upaya memberikan pembinaan kepada para guru. Guru pendidikan jasmani yang menjadi bagian dari proses pembelajaran di sekolah memiliki tugas pokok, yaitu mengefektifkan proses belajar mengajar dalam mencapai tujuan. Pelaksanaan pengawasan dengan model yang tepat akan mampu menghasilkan perubahan terhadap guru dalam menjalankan tugasnya sebagai pendidik.

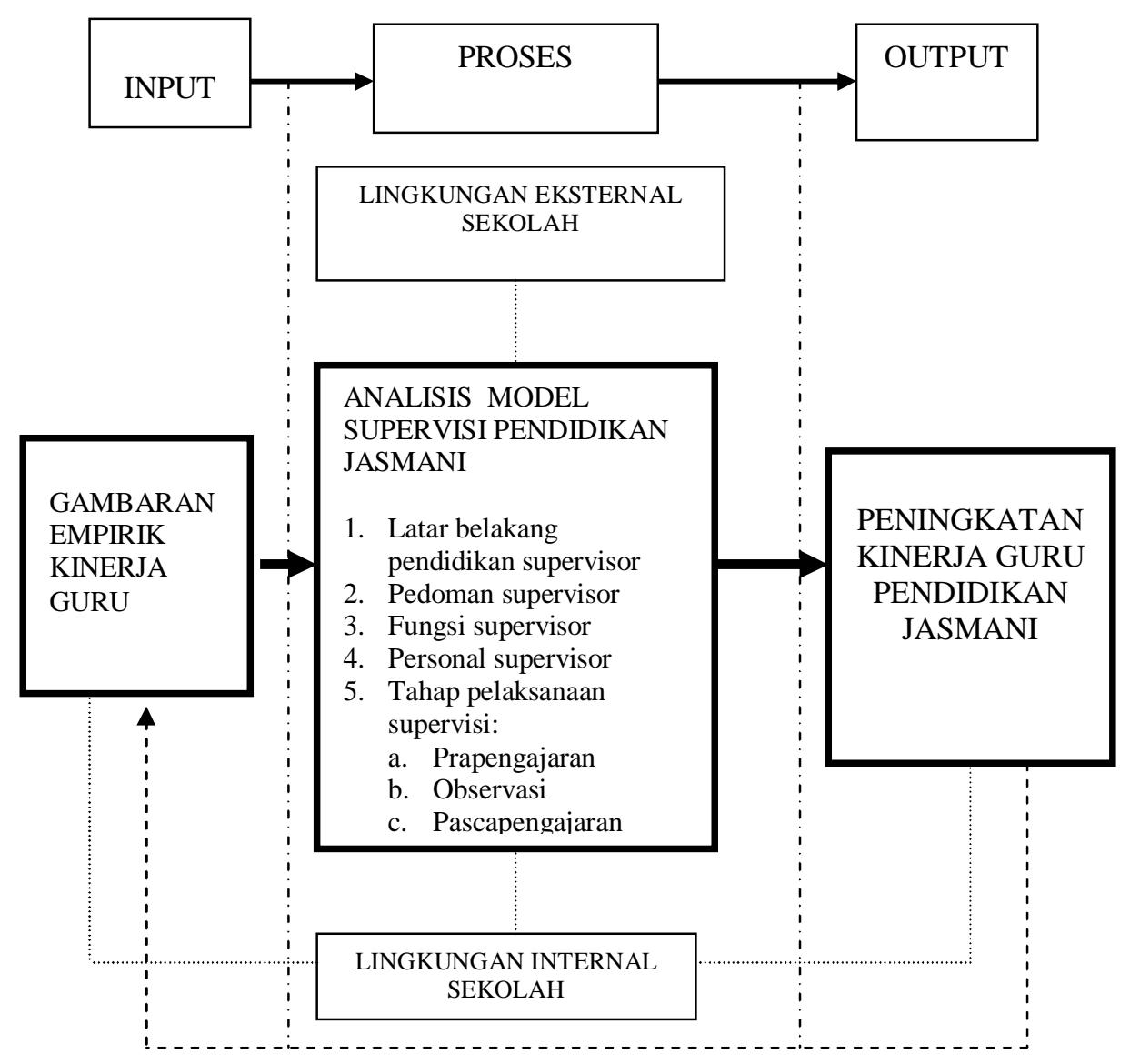

Gambar 1: Model Supervisi Metzler's PEIS

Jadi, efektivitas pengawasan dalam pembelajaran pendidikan jasmani dapat disimpulkan sebagai berikut.

- Pengawasan pembelajaran pendidikan jasmani hendaknya secara langsung mempengaruhi dan mengem- bangkan perilaku guru pendidikan jasmani, terutama di dalam merancang, mengelola, menilai dan mengembangkan proses pembelajaran pendidikan jasmani di sekolah. 
- Perilaku pengawas pendidikan jasmani dalam membantu para guru pendidikan jasmani mengembangkan kemampuan profesional dan moralnya hendaknya dirancang sedemikian rupa secara resmi sehingga terarah pada tujuan tertentu yang diharapkan.

- Pengawasan pembelajaran pendidikan jasmani merupakan tanggung jawab bersama antara pengawas dan guru pendidikan jasmani itu sendiri. Karena itu, dalam merancang dan mengembangkan program kegiatannya dapat dilakukan bersama-sama.

- Tujuan akhir dari pengawasan pembelajaran pendidikan jasmani adalah agar guru pendidikan jasmani semakin mampu secara profesional dan moral dalam memfasilitasi dan mengelola pembelajaran pendidikan jasmani bagi para siswanya.

- Pengawasan pembelajaran pendidikan jasmani sebagai suatu profesi harus didukung oleh latar belakang keilmuan yang terkait dan ditopang oleh berbagai teori yang dibutuhkan. Artinya, untuk menjadi seorang supervisor pendidikan jasmani yang profesional, perlu memiliki latar belakang keilmuan yang terkait dan memadai, serta didukung oleh berbagai teori keilmuan lain yang dibutuhkan, seperti: teori belajar, teori kepribadian, teori komunikasi, teori organisasi dan dinamikan kelompok.

\section{METODE}

Secara metodologis, penelitian ini dirancang menggunakan pendekatan kualitatif dengan subjek terbatas, metode deskriptif dengan studi kasus, dan prosedur penelitian dan pengembangan. Penelitian perkembangan menurut Arikunto (2005:239) merupakan penelitian yang dimaksudkan untuk mencoba mengetahui perkembangan subjek, misalnya perkembangan kurikulum dari waktu ke waktu. Menurut Borg dan Gall (1983:772), educational research and development $(R \mathcal{E} D)$ is a process used to develop and validate educational products. Jadi, prosedur penelitian dan pengembangan dalam pendidikan ini digunakan untuk mengembangkan dan memvalidasi hasil yang diperoleh pendidikan, dalam hal ini model pengawasan pembelajaran pendidikan jasmani di SD. Berdasarkan uraian di atas, prosedur penelitian untuk mengembangkan model pengawasan pembelajaran pendidikan jasmani di SD ini dilakukan dengan menerapkan sebuah prosedur penelitian dan pengembangan dengan langkah pelaksanaan secara konseptual sebagai berikut.

- Studi pendahuluan, studi ini dilakukan melalui penelitian kepustakaan dan lapangan. Studi kepustakaan, penulis lakukan dengan mengkaji teori, konsep, dan hasil penelitian yang relevan. Studi lapangan, penulis lakukan dengan teknik observasi, wawancara, dan studi dokumentasi dengan menggunakan pendekatan studi kasus yang selanjutnya dianalisis secara kualitatif untuk memeriksa model pengawasan pembelajaran pendidikan jasmani yang telah ada di SD.

- Mengembangkan model awal, pengembangan model awal pengawasan pembelajaran pendidikan jasmani SD berdasarkan pada hasil studi pendahuluan yang terjadi di lapang- 
an dan kajian kepustakaan. Teknik ini didasarkan pada kondisi kebutuhan subjek sehingga proses pembuatannya akan melibatkan para pengawas, kepala sekolah, dan guru pendidikan jasmani.

- Melakukan uji coba terhadap model, validasi terhadap model yang telah penulis buat, selanjutnya dilakukan oleh para ahli dan praktisi pendidikan atau expert judgment. Validasi terhadap ahli dilakukan melalui diskusi intensif terhadap model konseptual yang telah dibuat dengan pihak ahli yang ada di perguruan tinggi. Adapun kepada para praktisi pendidikan diupayakan melalui observasi, wawancara, dan angket pada subjek terbatas, yaitu: guru dan kepala sekolah dari beberapa SD serta pengawas sekolah TK/SD dari beberapa wilayah di kota Bandung. Melakukan revisi model awal, revisi model dilakukan setelah melalui proses validasi baik oleh para ahli maupun praktisi. Selanjutnya, dibuatlah sebuah model secara konseptual yang siap untuk diimplementasikan oleh peneliti di lapangan.

- Melakukan ujicoba lapangan, melakukan ujicoba lapangan yang dilanjutkan dengan melakukan observasi, wawancara, dan angket. Keseluruhan dari proses ujicoba ini datanya akan dikumpulkan untuk selanjutnya hasilnya dievaluasi untuk memperoleh rumusan pasti mengenai model hasil uji coba lapangan.

\section{HASIL}

Ada beberapa temuan yang diperoleh dari penelitian ini terkait dengan hal-hal sebagai berikut.

\section{Model Pengawasan Pembelajaran Pen- didikan Jasmani yang Dilaksanakan oleh Pengawas}

Model pelaksanaan pengawasan pembelajaran pendidikan jasmani yang dilaksanakan di SD saat ini adalah segala upaya yang dilakukan oleh kepala sekolah dan pengawas sebagai supervisor dalam melaksanakan penilaian dan pembinaan terhadap satuan pendidikan yang menjadi tanggungjawabnya, dengan penekanan pada proses pembelajaran di kelas. Melalui rangkaian pembimbingan dan layanan optimal kepada guru pendidikan jasmani tersebut bertujuan untuk meningkatkan kualitas pembelajaran di lapangan. Hasil penelitian yang diungkapkan pada bagian ini meliputi beberapa hal sebagai berikut.

- Pemahaman kepala sekolah dan pengawas sebagai supervisor belum sampai pada tugas dan fungsinya yang komprehensif karena keterbatasan dalam hal penguasaan substansi pembelajaran. Pembelajaran penjas di SD merupakan mata pelajaran bidang studi dan untuk membina dan menilainya pun diperlukan supervisor yang memiliki keahlian dalam bidang tersebut. Secara umum, pengawas di Kota Bandung yang memiliki kompetensi dalam substansi pendidikan jasmani SD tidak ada. Hal ini berdampak terhadap pelaksanaan pengawasan yang tidak menyentuh pada persoalan utama, yaitu pem- 
binaan dan penilaian pelaksanaan pembelajaran di lapangan. Kondisi ini diakui oleh para supervisor sebagai kendala utama dalam memberikan pembinaan dan penilaian terhadap para guru penjas.

- Pada umumnya para guru penjas berpendapat bahwa kepala sekolah dan pengawas selama ini baru dapat melakukan tugas-tugas administratif, seperti menjalankan pemeriksaan berupa dokumen KBM, RPP, program semester dan tahunan serta memotivasi guru untuk meningkatkan pengetahuan dalam mengajar. Kedua unsur ini sudah dapat terlaksana dengan baik selama pelaksanaan pengawasan, namun untuk unsur-unsur lain seperti memberikan bimbingan dan membantu guru dalam memperbaiki dan meningkatkan mutu PBM, mengoreksi dan memperbaiki kesalahan guru dalam mengajar penjas di lapangan, memberikan contoh cara mengajar penjas di lapangan, menjadi nara sumber atau fasilitator dalam pembelajaran penjas, serta membina dan minilai kinerja guru penjas masih belum dapat berjalan secara optimal.

- Hubungan antara guru pendidikan jasmani dengan kepala sekolah dan pengawas sekolah dalam kaitannya dengan upaya memperbaiki pembelajaran pendidikan jasmani di SD masih harus terus ditingkatkan. Hubungan kedua belah pihak masih harus terus dijalin hingga diperoleh hubungan ideal, yakni terciptanya suasana kondusif yang dibutuhkan dalam pelaksanaan pengawasan. Realitas ini lebih dikarenakan ter- dapat kesan seolah-olah guru penjas di sekolah kurang memberikan kontribusi signifikan dalam meningkatkan kualitas pendidikan secara keseluruhan sebagai dampak dari tidak sinergisnya hubungan kedua belah pihak dalam menjalankan tugas masing-masing.

- Kegiatan-kegiatan yang dilakukan oleh kepala sekolah dan pengawas sekolah sebagai supervisor sejauh ini masih belum berjalan efektif. Hal tersebut nampak dalam temuan di lapangan sebagai berikut.

- Kesiapan guru untuk dikunjungi, kegiatan ini bentuknya pemeriksaan kelengkapan administrasi mengajar, perlengkapan, dan media pembelajaran penjas yang dilakukan guru menjadi target utama yang dilakukan supervisor. Hal ini memperjelas bahwa pengawasan tertuju pada kegiatan administratif guru, sehingga guru penjaspun cukup menyiapkan perangkat itu saja untuk keperluan pelaksanaan pengawasan.

- Maksud dan tujuan kunjungan kelas, seperti untuk mengetahui KBM yang sebenarnya, untuk menilai kemampuan guru saat mengajar, dan untuk memeriksa kesesuaian antara rencana dan pelaksanaan belum memperoleh perhatian dalam pelaksanaan pengawasan. Kondisi ini membuktikan bahwa upaya memperbaiki proses belajar mengajar penjas SD belum dilaksanakan dengan baik.

- Frekuensi kunjungan kelas yang dilakukan supervisor belum teragendakan secara rutin dan men- 
jadi tanggung jawabnya dalam meningkatkan kinerja guru penjas. Bahkan, dari hasil temuan di lapangan diperoleh data rata-rata sebesar 40,7\% dengan frekuensi kunjungan setiap bulan hanya untuk menanyakan kelengkapan olahraga, 1 semester sekali digunakan untuk melihat-lihat saja, 1 tahun sekali dimanfaatkan untuk penilaian DP3.

- Pertimbangan memilih guru untuk dikunjungi hanya dilakukan untuk kepentingan administrasi. Artinya, pengawasan lebih mengutamakan hal-hal administratif. Karena halhal lain, seperti permintaan guru sendiri, guru bermasalah dalam pembelajaran, hasil belajar siswa yangkurangmemuaskan, dan mendorong guru untuk mengikuti pelatihan dan penataran belum menjadi prioritas dalam pelaksanaan kunjungan yang dilakukan para supervisor kepada guru penjas.

- Kegiatan selama di lapangan hanya sebatas pada mengisi format observasi sedangkan mengamati guru dalam menerapkan metode mengajar dan penggunaan media pembelajaran belum tersentuh secara signifikan.

- Sikap guru selama diobservasi secara umum sangat senang dan kooperatif karena mengharapkan adanya berbagai inovasi yang diperlukan dalam meningkatkan kualitas pembelajarannya. Adapun pengawasan dianggap hal biasa sangatlah kecil.

- Cara menyampaikan hasil observasi pada umumnya dilakukan se- cara tidak langsung, sehingga hal ini kurang membantu para guru pendidikan jasmani untuk memperbaiki berbagai kekurangan yang dimilikinya saat mengajar. Ini juga menjadi kelemahan yang terjadi dan dirasakan dalam pelaksanaan pengawasan pada guru pendidikan jasmani di sekolah dasar.

- Format instrumen observasi yang selama ini digunakan pengawas dalam melakukan observasi kelas, sungguh tidak tepat apabila instrumen observasi itu digunakan pula kepada guru pendidikan jasmani SD. Seharusnya pengawas di tingkat SD membuat instrumen observasi yang cocok untuk mata pelajaran pendidikan jasmani. Ketidaktepatan instrumen dapat berakibat pada tidak akuratnya informasi yang dibutuhkan oleh pengawas. Oleh karena itu, pengembangan instrumen yang cocok sangat diperlukan saat ini.

- Program kerja kurang menyentuh secara substansi terhadap eksistensi guru pendidikan jasmani di SD. Hal ini semakin memperlebar keterpurukan yang dihadapi dalam pembelajaran pendidikan jasmani. Kondisi nyata di lapangan ini telah menjadi polemik berkepanjangan antara guru pendidikan jasmani dengan pengawas. Akibatnya, pembelajaran pendidikan jasmani menjadi tidak efektif dan berimplikasi langsung pada penurunan kualitas anak didik.

- Kegiatan KelompokKerja Guru (KKG) mata pelajaran pendidikan jasmani di SD menjadi salah satu wadah kerjasama dalam upaya meningkatkan 
profesionalisme guru dalam merencanakan, melaksanakan, dan menilai proses belajar mengajar. Masalah yang dibahas dalam kegiatan KKG bersumber pada kebutuhan guru sehari-hari. KKG dipimpin oleh pengurus yang terdiri dari ketua, sekretaris dan bendahara yang dipilih secara aklamasi oleh para guru sebagai anggota untuk masa bakti dua tahun ajaran. Anggota KKG pendidikan jasmani di Kota Bandung terdiri dari para guru penjas SDN dan SD Swasta. Upaya ini dilakukan karena para guru pendidikan jasmani telah mengetahui secara jelas akan maksud dan tujuan dari setiap kali pertemuan yang diselenggarakan, yaitu: (1) Kelompok Kerja Guru (KKG) digunakan sebagai wahana informasi guru penjas SD; (2) KKG dapat digunakan sebagai ajang tukar pendapat terutama dalam menyikapi permasalahan PBM; dan (3) KKG dapat digunakan sebagai wadah untuk peningkatan kompetensi guru penjas.
Efektivitas Model Pengawasan Pembelajaran Pendidikan Jasmani di SD

Untuk mengetahui efektivitas model pengawasan pembelajaran yang dikembangkan terhadap kinerja guru, maka disusun sebuah instrumen yang memuat uraian item unsur pengembangan model tersebut. Instrumen pengembangan model pengawasan pembelajaran tersebut diberikan sebagai tes awal (pretest) dan tes akhir (posttest).

\section{- Efektivitas model pengawasan pem-} belajaran pendidikan jasmani yang dikembangkan terhadap kinerja guru pendidikan jasmani SD

Hasil tes yang disajikan dalam Tabel 1 menunjukkan bahwa kinerja guru pendidikan jasmani SD di Kota Bandung mengalami peningkatan setelah diberikan model pengawasan pembelajaran yang dikembangkan. Analisis efektivitas model pengawasan pembelajaran yang dikembangkan terhadap kinerja adalah sebagai berikut.

\section{Tabel 1. ANOVA Efektivitas Model Pengawasan Pembelajaran terhadap Kinerja Guru Pendidikan Jasmani SD}

\begin{tabular}{lcccccc}
\hline Sumber Variasi & $\mathrm{dk}$ & $\mathrm{JK}$ & $\mathrm{RJK}$ & $\mathrm{Fh}$ & $\mathrm{Ft}(0,05)$ & Keputusan \\
\hline $\begin{array}{l}\text { Antar } \\
\text { Kelompok }\end{array}$ & 1 & 555,025 & 555,025 & & & $\begin{array}{c}\text { Fh }>\text { Ft } \\
\text { Ho ditolak } \\
\text { artinya } \\
\text { terdapat }\end{array}$ \\
$\begin{array}{l}\text { Dalam } \\
\text { Kelompok }\end{array}$ & 38 & 4057,950 & 106,788 & 5,197 & 4,08 & $\begin{array}{c}\text { perbedaan } \\
\text { Total }\end{array}$ \\
\hline
\end{tabular}

Hasil yang tertuang pada Tabel tersebut menunjukkan bahwa F hitung sebesar 5,197 dibandingkan dengan harga F tabel dengan taraf kesalahan 0,05, maka harga $F$ tabel sebesar 4,08. Ter- nyata, F hitung lebih besar daripada $\mathrm{F}$ tabel sehingga dapat dinyatakan Ho ditolak. Oleh karena Ha diterima, artinya terdapat perbedaan antara model pengawasan pembelajaran yang dikem- 
bangkan dengan model pengawasan sebelumnya. Untuk menyatakan bahwa perbedaan tersebut signifikan, maka harus dilanjutkan dengan uji signifikansi dengan menggunakan uji perbedaan dua sampel yaitu dengan uji-t. Hasil uji signifikansi dengan uji-t menunjukkan bahwa thitung sebesar 2,280 dan t tabel pada tingkat kepercayaan 0,05 sebesar 2,021. Jadi, $t$ hitung lebih besar daripada $\mathrm{t}$ table. Hal ini berarti terdapat perbedaan secara signifikan kinerja guru pendidikan jasmani SD sebelum dan setelah diberikan perlakuan model pengawasan pembelajaran yang dikembangkan. Artinya, model pengawasan yang dilakukan selama ini berbeda dengan model yang dikembangkan dalam penelitian.

Kesimpulan mengenai efektivitas model pengawasan pembelajaran ter- hadap peningkatan kinerja guru pendidikan jasmani telah membuktikan bahwa model pengawasan pembelajaran yang dikembangkan dapat meningkatkan kinerja guru pendidikan jasmani SD di Kota Bandung.

- Efektivitas model pengawasan pembelajaran pendidikan jasmani yang dikembangkan terhadap hasil belajar siswa dalam mata pelajaran pendidikan jasmani SD

Hasil tes awal dan tes akhir mengenai hasil belajar siswa dalam mata pelajaran pendidikan jasmani SD di Kota Bandung memperlihatkan ada pengaruh. Hal ini terlihat dari selisih rata-rata hasil belajar antara tes awal dan tes akhir seperti yang terlihat pada Tabel 2.

Tabel 2. Rata-rata dan Simpangan Baku Tes Awal dan Tes Akhir Hasil Belajar Siswa dalam Mata Pelajaran Pendidikan Jasmani SD

\begin{tabular}{lccc}
\hline Pelaksanaan Tes & $\begin{array}{c}\text { Rata-rata Hasil } \\
\text { Belajar }\end{array}$ & $\begin{array}{c}\text { Simpangan Baku Hasil } \\
\text { Belajar }\end{array}$ & Keterangan \\
\hline Tes Awal & 7,83 & 0,59 & \\
Tes Akhir & 8,03 & 0,56 & \\
\hline
\end{tabular}

Hasil tes yang disajikan dalam tabel tersebut menunjukkan bahwa hasil belajar siswa dalam mata pelajaran pendidikan jasmani SD di Kota Bandung mengalami peningkatan setelah diberi- kan model pengawasan pembelajaran yang dikembangkan. Analisis efektivitas model pengawasan pembelajaran yang dikembangkan terhadap hasil belajar adalah sebagai berikut.

\section{Tabel 3. ANOVA Efektivitas Model Pengawasan Pembelajaran terhadap Hasil Belajar Siswa dalam Mata Pelajaran Pendidikan Jasmani SD}

\begin{tabular}{lcccccc}
\hline Sumber Variasi & $\mathrm{dk}$ & $\mathrm{JK}$ & $\mathrm{RJK}$ & $\mathrm{Fh}$ & $\mathrm{Ft}(0,05)$ & Keputusan \\
\hline Antar Kelompok & 1 & 3,758 & 3,758 & & & $\begin{array}{c}\text { Fh }>\text { Ft } \\
\text { Ho ditolak artinya } \\
\text { terdapat } \\
\text { perbedaan }\end{array}$ \\
Dalam Kelompok & 398 & 132,104 & 3,758 & 11,321 & 3,89 & \\
\hline
\end{tabular}


Hasil yang tertuang pada tabel tersebut menunjukkan bahwa F hitung sebesar 11,321 dibandingkan dengan harga $\mathrm{F}$ tabel dengan taraf kesalahan 0,05, maka harga $\mathrm{F}$ tabel sebesar 3,89. Ternyata, $\mathrm{F}$ hitung lebih besar daripada $\mathrm{F}$ tabel, sehingga dapat dinyatakan Ho ditolak. Ha diterima, artinya terdapat perbedaan antara model pengawasan pembelajaran yang dikembangkan dengan model pengawasan sebelumnya. Untuk menyatakan bahwa perbedaan tersebut signifikan, maka harus dilanjutkan dengan uji signifikansi dengan menggunakan uji perbedaan dua sampel, yaitu dengan uji-t. Hasil uji signifikansi dengan uji-t menunjukkan bahwa t hitung sebesar 5,892 dan $\mathrm{t}$ tabel pada tingkat kepercayaan 0,05 sebesar 1,960. Jadi, $\mathrm{t}$ hitung lebih besar daripada $\mathrm{t}$ tabel. Hal ini berarti terdapat perbedaan secara signifikan hasil belajar siswa dalam mata pelajaran pendidikan jasmani SD sebelum dan setelah diberikan perlakuan model pengawasan pembelajaran yang dikembangkan.

Kesimpulan mengenai efektivitas model pengawasan pembelajaran terhadap peningkatan hasil belajar siswa dalam mata pelajaran pendidikan jasmani telah membuktikan bahwa model pengawasan pembelajaran yang dikembangkan dapat meningkatkan hasil belajar siswa dalam mata pelajaran pendidikan jasmani SD di Kota Bandung. Dengan kata lain, model pengawasan pembelajaran yang dikembangkan dalam penelitian ini sangat efektif dalam meningkatkan hasil belajar siswa dalam mata pelajaran pendidikan jasmani SD di Kota Bandung

\section{PEMBAHASAN}

Mengacu pada hasil pengolahan data penelitian dan analisis data, pembahasan dalam penelitian ini sebagai berikut.

\section{Model Pengawasan Pembelajaran Pen- didikan Jasmani Saat Ini}

Kepala sekolah dan pengawas secara umum sudah memahami perannya sebagai supervisor pembelajaran pendidikan jasmani di SD. Namun, dalam pelaksanaan di lapangan belum nampak korelasi antara pemahaman dan implementasi. Kondisi ini lebih disebabkan karena terlalu terpola dengan kegiatan rutin administratif yang banyak menyita waktu sehingga peranannya sebagai pembina maupun pembimbing guru dalam meningkatkan kinerja menjadi terabaikan.

Dengan belum sinkronnya peranan kepala sekolah dan pengawas sekolah sebagai pengawas pengajaran terhadap kinerja guru, menjadikan pelaksanaan pengawasan yang menjadi ujung tombak dalam meningkatkan mutu kinerja guru semakin tidak jelas. Oleh karena itu, hubungan antara guru pendidikan jasmani dengan kepala sekolah dan pengawas sekolah dalam kaitannya dengan upaya memperbaiki pembelajaran pendidikan jasmani di SD harus terus diupayakan.

Komponen administratif berupa perencanaan pembelajaran selalu menjadi prioritas dalam melakukan pengawasan ke sekolah. Pembinaan yang diberikan terhadap guru pendidikan jasmani SD sangat tidak jelas karena pengawasnya kurang memahami apa yang seharusnya disupervisi. Kondisi ini semakin 
diperparah dengan latar belakang pengawas yang sama sekali tidak memahami materi (content) pendidikan jasmani, sehingga guru pendidikan jasmani SD tidak ada fasilitas yang dapat dijadikan tempat "curhat".

Jadi, pelaksanaan pengawasan pembelajaran pendidikan jasmani saat ini di SD hanya bersifat administratif. Oleh karena itu, supaya pengawas dapat menjalankan tugasnya sebagai pengawas harus memiliki perencanaan tugas pokok, yaitu: program peningkatan mutu pendidikan di sekolah dasar (SD) dapat dicapai bila kegiatan proses belajar mengajar di kelas dapat berlangsung dengan baik, efektif dan efisien. Hal tersebut dapat terlaksana apabila ditunjang dengan adanya upaya peningkatan kemampuan guru pendidikan jasmani dalam mengelolanya.

Sejak diberlakukannya ketentuan Jabatan Fungsional Pengawas Sekolah pada tanggal 1 November 1996, kemudian ditindaklanjuti dengan keputusan yang mengatur petunjuk pelaksanaan dan petunjuk teknis pelaksanaan Jabatan Fungsional dan angka kreditnya melalui Keputusan Mendikbud Nomor 020 U/1998, tugas pengawas sekolah mengalami beberapa perubahan sehingga perlu disikapi secara bijaksana dan tepat. Oleh karena itu, pengawas sekolah dituntut untuk mampu menjabarkan tugas pokok dan tugas rutin dalam sebuah kerangka pengelolaan strategi pelaksanaan tugas (manajemen) dengan memanfaatkan rentang waktu yang tersedia. Ada tiga hal pokok yang penulis temukan dalam mekanisme pengawasan oleh supervisor tingkat SD di Kota Bandung, yaitu: (1) manajemen kepengawasan; (2) strategi pelaksanaan tugas; dan (3) inventarisasi dan pemetaan kegiatan pengawas SD

Adapun tugas pokok pengawas sekolah tingkat SD berdasarkan pada SK Mendikbud Nomor 020//1998 dan wajib dilaksanakan oleh pengawas sekolah yang diberi tugas oleh koordinator pengawas sekolahm, yaitu: (1) menyusun program tahunan pengawasan sekolah tingkat Kabupaten/Kota; (2) menyusun soal/instrumen penilaian; dan (3) melaksanakan evaluasi hasil pengawasan dari seluruh sekolah yang ada di lingkungan Kabupaten/Kota.

\section{Efektivitas Model Pengawasan Pem- belajaran Pendidikan Jasmani}

Efektivitas model pengawasan pembelajaran yang dikembangkan terhadap kompetensi pengelolaan pembelajaran guru pendidikan jasmani SD. Bagi guru pengelolaan pembelajaran sudah menjadi aktivitas rutin dan juga menjadi fokus dalam pengawasan oleh pengawas. Jadi, kompetensi pengelolaan pembelajaran atau yang lebih umum disebut aktivitas administratif bukan persoalan karena yang selalu diawasi oleh pengawas selama proses pengawasan yang dipertanyakan hanya kondisi administrasi yang dilakukan guru. Oleh karena itu, tidaklah heran apabila perlakuan berupa model pengawasan yang dikembangkan dalam penelitian ini pengaruhnya tidak signifikan terhadap kompetensi pengelolaan pembelajaran.

Efektivitas model pengawasan pembelajaran yang dikembangkan terhadap kompetensi akademik guru pendidikan jasmani SD. Selama ini guru tidak 
pernah mendapatkan pembinaan secara rutin dari pengawas mengenai apa yang harus dan perlu diterapkan saat guru sedang mengajar di lapangan. Melalui perlakuan selama proses penelitian ternyata kompetensi akademik dapat meningkat dan tentunya dapat memberi dampak terhadap kualitas pengajaran bagi para siswanya. Jadi, model pengawasan pembelajaran yang dikembangkan terbukti efektif dalam meningkatkan kompetensi akademik guru pendidikan jasmani di SD.

Efektivitas model pengawasan pembelajaran yang dikembangkan terhadap kompetensi pengembangan profesi guru pendidikan jasmani SD. Melalui proses pembinaan secara teratur selama pelaksanaan pengawasan, guru pendidikan jasmani SD menjadi lebih meningkat kompetensi pengembangan profesinya. Guru lebih termotivasi untuk melakukan penelitian (PTK) atau bergabung dengan organisasi seperti KKG untuk sharing dalam memperoleh berbagai informasi yang diperlukan dalam meningkatkan kualitas pengajarannya sehingga lebih profesional.

Efektivitas model pengawasan pembelajaran yang dikembangkan terhadap kinerja guru pendidikan jasmani SD. Peningkatan kinerja guru pendidikan jasmani SD ini lebih dikarenakan faktor pembinaan yang diberikan selama pelaksanaan pengawasan pembelajaran. Pengawasan yang dilakukan selama proses penelitian telah mendorong guru pendidikan jasmani untuk lebih serius dalam menjalankan tugasnya sebagai pendidik, sehingga perubahan sangat dirasakan. Kesalahan dan ketidaktahuan guru dalam melakukan berbagai ak- tivitas pembelajaran dapat teratasi dengan diberikannya serangkaian pembinaan sebelum, pada saat, dan setelah pembelajaran selesai. Guru pendidikan jasmani merasa terbantu dengan keberadaan pengawas di lapangan.

Efektivitas model pengawasan pembelajaran yang dikembangkan terhadap hasil belajar siswa dalam pembelajaran pendidikan jasmani SD. Peningkatan hasil belajar siswa dalam mata pelajaran pendidikan jasmani SD ini lebih dikarenakan faktor pembelajaran yang lebih bermutu setelah guru memperoleh pembinaan yang diberikan oleh pengawas selama pelaksanaan penelitian.

Sejalan dengan penyampaian informasi mengenai hasil penelitian ini, cukup masuk akal apabila kinerja guru pendidikan jasmani di tingkat SD selalu menjaga kemampuannya selama pembelajaran serta memerlukan layanan pengawasan yang terstruktur dari pengawas. Melalui pelaksanaan pengawasan yang tepat akan dapat memberikan implikasi berarti terhadap kinerja guru pendidikan jasmani, yakni efektif dalam mengajarkan dan dapat memaksimalkan siswa dalam aktivitas pembelajaran. Persoalan ini menjadi rumit manakala pengawas kurang memberikan layanan pengawasan yang optimal terhadap guru diikuti dengan terlalu otoriter dalam menjalankan tugasnya sebagai pengawas pembelajaran yang pada akhirnya akan berdampak terhadap rendahnya mutu pendidikan. Sikap kaku yang sering ditampilkan oleh para pengawas saat melakukan pengawasan menjadikan kegiatan 
pengawasan menjadi tidak efektif dan menyentuh sasaran.

Dengan penerapan model pengawasan yang dikembangkan ini, telah dapat diperoleh beberapa manfaat seperti berikut.

- Adanya kesamaan gerak langkah semua pengawas sekolah se Kota Bandung sehingga pemantauan kegiatan pengawas oleh pimpinan struktural yang terkait (Kasi Kurikulum Pendidikan Dasar, Kasi Tenaga Kepengawasan Dinas Pendidikan Kota Bandung) dapat dilaksanakan secara terprogram dan berkesinambungan.

- Kriteria keberhasilan program lebih mudah ditetapkan untuk lingkungan masing-masing.

- Memudahkan pengawas sekolah menentukan skala prioritas kegiatan untuk penyusunan program pengawasan setiap semester.

Namun demikian, ada pula kendala yang dihadapi para pengawas selama menjalankan tugas pengawasannya. Ada dua kendala utama yang sering dihadapi selama pelaksanaan pengawasan di sekolah, yaitu: kendala psikologis dan kendala teknik.

- Kendala secara psikologis yang sering ditemui oleh para supervisor di lapangan, yaitu: (1) merasa puas dengan keberhasilan yang telah dicapai; (2) merasa telah berpengalaman; (3) merasa takut salah; (4) takut dicemoohkan orang lain; (5) cepat patah semangat; (6) menginginkan rasa aman; (7) tidak mau sulit/idak menginginkan tantangan; dan (8) mencari kambing hitam.

- Beberapa kendala teknis yang sering ditemukan dalam pelaksanaan peng- awasan di tingkat SD, yaitu: (1) keragaman latar belakang pendidikan; (2) perubahan dan kemajuan IPTEK menuntut penyesuaian layanan pendidikan; (3) perjalanan waktu menciptakan kejenuhan; (4) penataran tidak memadai; dan (5) keterbatasan sarana dan alat.

\section{PENUTUP}

\section{Kesimpulan}

Kesimpulan penelitian ini adalah bahwa model pengembangan pengawasan pembelajaran pendidikan jasmani yang dilakukan pada guru SD telah terbukti memberikan dampak pada meningkatnya kinerja dan hasil belajar siswa. Artinya, model pengawasan yang dikembangkan ini dapat digunakan untuk memperbaiki mekanisme pengawasan terhadap guru pendidikan jasmani SD yang selama ini hanya berorientasi pada unsur administratif semata. Pengawas yang tidak berlatar belakang pendidikan jasmanipun dapat ikut belajar dengan guru pendidikan jasmani dalam merumuskan pola pengawasan yang sinergis sehingga akan didapat model pengawasan pembelajaran yang lebih komprehensif dan maslahat bagi kedua belah pihak. Meskipun idealnya untuk pengawasan pembelajaran pendidikan jasmani ini diperlukan pengawas yang memiliki latar belakang guru pendidikan jasmani SD, sehingga akan diperoleh hasil yang lebih optimal dalam pelaksanaan pengawasannya.

\section{Saran}

Saran-saran yang diusulkan adalah bahwa pengawas pendidikan jasmani 
SD sebaiknya berlatar belakang guru pendidikan jasmani dan tidak perlu ada segregation dalam melaksanakan tugas pengawasan di antara jenjang pendidikan (SD s/d SLTA). Pegawas harus profesional dengan latar belakang keilmuan/otoritas. Optimalisasi model pengawasan pembelajaran pendidikan jasmani di SD melalui pendekatan kolaborasi pengawas, kepala sekolah, dan guru dalam wadah KKG akan dapat menjalankan tugasnya secara lebih arif dan bijaksana terutama dalam hal memberikan perlakuan yang demokratis terhadap guru sebagai bawahannya. Untuk melaksanakan evaluasi kinerja guru pendidikan jasmani SD, kepemilikan kompetensi dan motivasi sangat mendukung. Meskipun peranan guru sangat dominan, namun keberhasilannya dapat diandalkan, terutama untuk jumlah siswa besar dan waktu yang terbatas. Penelitian selanjutnya diperlukan dalam lingkup yang lebih luas karena diketahui masih banyak hal-hal lain yang belum tergali secara mendalam dan memerlukan waktu dan dana yang lebih banyak dalam mengeksplorasinya.

\section{UCAPAN TERIMA KASIH}

Terima kasih saya ucapkan kepada Redaktur Jurnal Cakrawala Pendidikan yang telah memberi input untuk penyempuraan artikel ini. Terima kasih juga diucapkan kepada staf Jurnal Cakrawala Pendidikan Universitas Negeri Yogyakarta yang ikut memberi andil terhadap penerbitan artikel ini.

\section{DAFTAR PUSTAKA}

Alfonso, R.J. Firth, G.R, dan Neville,R.F. 1981._Instructional Supervision: A Behavour System. Boston: Allyn and Bacon, Inc.

Arikunto, Suharsimi. 2005. Manajemen Penelitian. Edisi Revisi. Jakarta: PT. Rineka Cipta.

Borg, WR. Dan Gall, MD. 1983. Educational Research: An Introduction. Edisi ke- 4. New York: Longman, Inc.

Corbin, BC., Dowell, JL., Lindsey R., dan Tolson, H., 1979. Concepts in Physical Education with Laboratories and Experientis. Edisi ke-3. Iowa: Wm.C. Brown Company Publishers.

Depdiknas. 2003. Undang-undang Sistem Pendidikan Nasional. Jakarta: Departemen Pendidikan Nasional.

Dharma, Agus. 2001. Manajemen Supervisi. Edisi Ke-4. Jakarta: PT. Raja Grafindo Persada.

Furqon. 2006. Pengawas Kok Minta Fasilitas ke Sekolah yang Diawasi. Bandung: Harian Umum "PR" 9 Oktober 2006 hal 17.

Hyland, D. A. 1990. Philosophy of Sport. Edisi ke-1. USA: Paragon House.

Lavay W.B., French R., dan Henderson L.H., 1997. Positive Behavior Management Strategies for Physical Educators. USA: Human Kinetics. 
Metzler W. Michael. 1990. Instructional Models for Physical Education. Champaign: Human Kinetics Books.

Muhajir, N. 1998. Metodologi Penelitian Kualitatif. Yogyakarta: Rake Sara$\sin$.

Sergiovanni, T.J dan Starratt, R.J. 1993. Supervision: A Redefinition. New York: McGraw-Hill, Inc.

Soetjipto dan Kosasi, R. 1999. Profesi Keguruan. Jakarta: Rineka Cipta. 